\author{
Marquette University \\ e-Publications@Marquette
}

College of Nursing Faculty Research and

Publications

Nursing, College of

$11-2013$

\title{
Embracing a Competency-Based Specialty Curriculum for Community-Based Nursing Roles
}

\author{
Pamela F. Levin \\ Rush University \\ Susan M. Swider \\ Rush University \\ Susan Breakwell \\ Marquette University \\ Julia M. Cowell \\ Rush University \\ Virginia Reising \\ Erie Family Health Center
}

Follow this and additional works at: https://epublications.marquette.edu/nursing_fac

Part of the Nursing Commons

\section{Recommended Citation}

Levin, Pamela F.; Swider, Susan M.; Breakwell, Susan; Cowell, Julia M.; and Reising, Virginia, "Embracing a Competency-Based Specialty Curriculum for Community-Based Nursing Roles" (2013). College of Nursing Faculty Research and Publications. 259.

https://epublications.marquette.edu/nursing_fac/259 
Marquette University

e-Publications@Marquette

\section{Nursing Faculty Research and Publications/College of Nursing}

This paper is NOT THE PUBLISHED VERSION; but the author's final, peer-reviewed manuscript. The published version may be accessed by following the link in the citation below.

Public Health Nursing, Vol. 30, No. 6 (November/December 2013): 557-565. DOI. This article is (C) Wiley and permission has been granted for this version to appear in e-Publications@Marquette. Wiley does not grant permission for this article to be further copied/distributed or hosted elsewhere without the express permission from Wiley.

\section{Embracing a Competency-Based Specialty Curriculum for Community-Based Nursing Roles}

Pamela F. Levin

Department of Community, Systems and Mental Health Nursing, College of Nursing, Rush University, Chicago, Illinois

Susan M. Swider

Department of Community, Systems and Mental Health Nursing, College of Nursing, Rush University, Chicago, Illinois

Susan Breakwell

College of Nursing, Institute for End of Life Care, Marquette University, Milwaukee, Wisconsin

Julia M. Cowell

Department of Community, Systems and Mental Health Nursing, College of Nursing, Rush University, Chicago, Illinois

Virginia Reising

Adolescent Health, Erie Family Health Center, Chicago, Illinois 


\section{Abstract}

The Quad Council competencies for public health nursing (PHN) provide guidance in developing curricula at both the generalist and specialist level. However, these competencies are based on nursing roles in traditional public health agencies and community/public health is defined more broadly than official agency practice. The question arises as to whether community-based specialties require largely the same knowledge and skill set as PHN . The purpose of the competency cross-mapping project reported here was to (a) assess the intersection of the Quad Council competencies with four community-based specialties and (b) ensure the appropriateness of a Quad Council-based curriculum to prepare graduates across these four specialties (home health, occupational health, environmental health, and school nursing). This article details the multistep cross-mapping process, including validation with practice leaders. Results indicate strong alignment of community-based specialty competencies with Quad Council competencies. Community-based specialty-specific content that did not align well is identified, along with examples of didactic and clinical strategies to address gaps. This work indicates that a Quad Council-based curriculum is appropriate to prepare graduates in community-based specialties when attention to the specialty-specific competencies in the clinical setting is included. This work guides the development of a doctorate of nursing practice curriculum in PHN , encompassing the four additional community-based specialties.

Over the past decade, nursing practice has moved towards a competency-based format, whereby nurses are expected to demonstrate specific competencies for safe and effective practice (American Nurses Association [ANA], 2010a). In response to this, nursing education programs have moved to teaching in a competency-based manner, recognizing that to attain some competencies practice experience will be required. Public health nursing (PHN) has been a bit slower to adopt practice competencies, in part due to the breadth of practice models in existence for public health nurses and in part due to PHN practice's unique role as a synthesis of both nursing and public health (Carter, Kaiser, O'Hare, \& Callister, 2006; Oppewal, Lamanna, \& Glenn, 2006; Swider et al., 2006). The Council on Linkages between Academia and Public Health Practice (Council on Linkages) developed core competencies for public health professionals in 2001 (Council on Linkages Between Academia \& Public Health Practice, 2010a). Building on this, the Quad Council of Public Health Nursing Organizations (Quad Council) adapted the Council on Linkages document to reflect competencies for PHN practice across the two levels of generalist nurse and specialist/administrator (2003). These competencies are being used increasingly in public health nursing practice and education (Issel, Ashley, Kirk, \& Bekemeier, 2012; Jakeway, Cantrell, Cason, \& Talley, 2006; Oppewal et al., 2006; Swider et al., 2006) and a revised version was released from the Quad Council (2011) reflecting recent updates in the Council on Linkages Between Academia and Public Health Practice (2010b) competencies for public health professionals.

The Institute of Medicine's Future of Nursing report challenges educational institutions to prepare nurses for practice through comprehensive programs relevant to contemporary practice (National Academy of Sciences, 2011). In PHN, one of the related challenges is the diversity of community-based roles and settings often considered under the rubric "Public Health Nursing" (ANA, 2007a), including home health nursing, occupational health nursing, school nursing, faith community nursing, and 
correctional/forensic nursing (ANA, 2007b; Ervin, 2002; Ivanov \& Blue, 2008; Levin et al., 2008). Although graduates of any nursing program should be prepared to meet entry level competencies for their practice, nursing students being prepared for an advanced nursing role in PHN need to be educated to meet their specialty-level competencies (American Association of Colleges of Nursing, 2006; ANA, 2007b; Levin et al., 2008). The work reported here was an effort to determine if competencies relevant to four select community-based roles were consistent with specialty-level practice competencies in PHN. In other words, were nurses prepared to meet specialty-level competencies as outlined by the Quad Council, also able to meet the competencies required in these four community-based roles? If not, what content or skills education was needed to prepare nurses adequately for these roles? Further, should PHN graduate-level educational programs be revised to address the broadest spectrum of competencies across related community-based nursing roles? In a first step to address these questions, this article documents a cross-mapping project of PHN specialtylevel competencies and competencies in four community-based areas: home health, occupational health, environmental health, and school nursing.

In our earlier work examining the Doctorate of Nursing Practice role in community-based specialties, the practice leaders we interviewed questioned the relevance of PHN competencies for their areas of practice (Swider et al., 2009). We focused on competencies because of the increasing trend towards competency-based education, as a measurable way of ensuring that students developed the knowledge and skills to practice to the full scope of their role. In addition, as faculty we realized the need to augment our prior work of mapping and revising a graduate-level PHN curriculum to the Quad Council competencies (Swider et al., 2006) to ensure that our curriculum was relevant to the nursing roles in which our students planned to practice. Accordingly, we chose to continue using the Quad Council competencies rather than to use a different set of competencies, such as the measurement criteria from the ANA's Public Health Nursing: Scope and Standards of Practice (2007b). Lastly, our faculty represented expertise in public health nursing, but each had an emphasis in one of these other community-based roles, including home health, occupational health, environmental health, and school nursing. As faculty, we were therefore prepared to review competencies in these four specific community-based specialties, as well as to guide the clinical application of universal concepts of public health within these four areas. Our faculty viewed this as an efficient and effective approach to guide curricular refinements. Thus, we focused this competency cross-mapping work on the aforementioned four community-based specialties rather than other community-based specialties, such as faith community or correctional nursing.

The purpose of this work therefore was twofold: (a) to cross-map the specialty level Quad Council competencies with other community-based competencies and (b) to ensure the appropriateness of a Quad Council-based curriculum to prepare graduates for advanced roles in community-based specialties.

\section{Cross-Mapping Process}

To assess the relevance for the Quad Council (2003) competencies to the four selected communitybased specialties, we engaged in a systematic cross-mapping process with several steps. First, in determining which community-based specialties to consider, we looked to the expertise of our faculty: home health, school, occupational health, and environmental health nursing. Next, we convened a 
panel of five nurse practice leaders, who met the criteria of being prepared at the graduate level in the specific specialty area and held regional and/or national leadership positions in their specialty. In addition, several of these leaders were involved in writing professional standards for their specialty. In partnership with these leaders, we identified what constituted competency documents for these four areas. The documents selected were as follows:

1. Home Health Nursing: Scope and Standards of Practice (ANA, 2008).

2. School Nursing: Scope and Standards of Practice (ANA, 2005).

3. Competencies in Occupational and Environmental Health Nursing (American Association of Occupational Health Nurses [AAOHN], 2007).

4. Principles of Environmental Health for Nursing Practice with Implementation Strategies (ANA, 2007a).

Next, an initial review of the above competency documents occurred where competencies related to the generalist role were differentiated from those related to the advanced role. Although competencies related to an advanced role are designed to build on the generalist statements (ANA, 2007b, 2010b; Quad Council, 2003), at times the documents did not specify any additional competency at the advanced role level. Therefore, when there was no advanced role competency specified, the generalist role competency statement was used. The Advanced Practice Registered Nurse (APRN) Consensus Model (APRN Consensus Work Group \& the National Council of State Boards of Nursing APRN Advisory Committee, 2008) specified that Advanced Public Health Nursing was not defined as an APRN role, so we excluded competencies specific to the APRN role that focused exclusively on the individual. In sum, the inclusion and exclusion criteria for this cross-mapping process were as follows:

1. Exclusion: competencies at the advanced role level that focused inclusively on the individual, including direct care to individuals, prescriptive authority, and differential diagnosis.

2. Inclusion: (a) competencies for the advanced role that aligned with a Quad Council competency and (b) generalist role competencies only when no additional advanced role competency was delineated.

The next step in the cross-mapping process began with identifying similar concepts between Quad Council and specialty competencies; the process entailed looking for congruent patterns or themes between the two documents. Patterns between the competencies were discussed until consensus on whether similar concepts were expressed. This approach of looking for similar concepts and congruency of patterns across documents is an approach we previously used (Swider et al., 2006) and is one which is used by others in competency mapping efforts (Pohl et al., 2009; Wells, Sarigiannis, \& Boulton, 2012). A research assistant with a background in public health nursing initially completed the cross-mapping specialty competencies to the Quad Council statements; then a faculty member reviewed this work for consistency and any issues were discussed and resolved by consensus. For example, it was agreed that a specialty competency statement could be cross-mapped to more than one Quad Council competency. Next, the faculty with experience in the community-based specialty validated the cross-mapping; disagreements were discussed and consensus reached. Therefore, three rounds of review were completed for each of the four competency grids. 
To facilitate the cross-mapping effort, we developed a grid structure to document where patterns emerged between the specialty competencies and the 68 Quad Council (2003) statements, which are distributed across eight competency domains. The eight competency domains are as follows: Analytical Assessment Skills, Policy Development/Program Planning Skills, Communication Skills, Cultural Competency Skills, Community Dimensions of Practice Skills, Basic Public Health Sciences Skills, Financial Planning and Management Skills, and Leadership and Systems Thinking Skills (see Table 1). Table 2 provides a partial example of this competency "crosswalk" for the home health specialty, where competency statements for the advanced role in home health were mapped to competencies in the Quad Council domain of Community Dimensions of Practice Skills. When no additional advanced level competency was delineated or conceptual link identified, a competency statement for the generalist role level was used. In the Table 2 example, we considered that the skills and knowledge needed to engage others in community activities and negotiating across sectors in the community were related conceptually to negotiating or consulting across providers, team members, and community-based agencies. In this example, our decision was based on agreement that, although wording used across the set of standards was not exactly similar, there were congruent patterns or themes. 
Table 1. Proportion of Quad Council Competencies by Domain Cross-Mapped with a Community-Based Specialty Competencies

\begin{tabular}{|c|c|c|c|c|c|}
\hline $\begin{array}{l}\text { Quad Council } \\
\text { competencies }\end{array}$ & & $\begin{array}{l}\text { Community-based } \\
\text { specialty competencies } \\
\text { mapping outcomes }\end{array}$ & & & \\
\hline Domains & $\begin{array}{l}\text { Distribution of Quad } \\
\text { Council competencies } \\
\text { across domains }(N=68)\end{array}$ & Home health nursing (\%) & $\begin{array}{l}\text { School } \\
\text { nursing } \\
(\%)\end{array}$ & $\begin{array}{l}\text { Occupational } \\
\text { health nursing } \\
\text { (\%) }\end{array}$ & $\begin{array}{l}\text { Environmenta } \\
\text { health (\%) }\end{array}$ \\
\hline Analytic Assessment Skills & 11 & $9(82)$ & $9(82)$ & $10(91)$ & $3(27)$ \\
\hline $\begin{array}{l}\text { Policy } \\
\text { Development/Program } \\
\text { Planning Skills } \\
\end{array}$ & 11 & $9(82)$ & $10(91)$ & $9(82)$ & $3(27)$ \\
\hline Communication Skills & 7 & $6(86)$ & $7(100)$ & $5(71)$ & $3(43)$ \\
\hline Cultural Competency Skills & 5 & $3(60)$ & $2(40)$ & $1(20)$ & $4(80)$ \\
\hline $\begin{array}{l}\text { Community Dimensions of } \\
\text { Practice Skills }\end{array}$ & 8 & $8(100)$ & $7(88)$ & $6(75)$ & $4(50)$ \\
\hline $\begin{array}{l}\text { Basic Public Health Sciences } \\
\text { Skills }\end{array}$ & 8 & $6(75)$ & $7(88)$ & $7(88)$ & $6(75)$ \\
\hline $\begin{array}{l}\text { Financial Planning and } \\
\text { Management Skills }\end{array}$ & 10 & $6(60)$ & $8(80)$ & $10(100)$ & 0 \\
\hline $\begin{array}{l}\text { Leadership and Systems } \\
\text { Thinking Skills }\end{array}$ & 8 & $8(100)$ & $8(100)$ & $8(100)$ & $4(50)$ \\
\hline Total & 68 & $55(81)$ & $58(85)$ & $56(82)$ & $30(44)$ \\
\hline
\end{tabular}

Table 2. Grid of Quad Council Competency Statements Cross-Mapped to Community-Based Specialty Competencies: Home Health Nursing Example

\begin{tabular}{|l|l|l|}
\hline $\begin{array}{l}\text { Selected competency statements from Quad } \\
\text { Council domain: Community Dimensions of } \\
\text { Practice Skillsa }\end{array}$ & $\begin{array}{l}\text { Home health nurse } \\
\text { (generalist)b }\end{array}$ & Advanced home health nurse \\
\hline $\begin{array}{l}\text { Establishes and maintains linkages with key } \\
\text { stakeholders }\end{array}$ & & $\begin{array}{l}\text { Facilitates the effectiveness of a consultation by involving } \\
\text { the patient and staff in decision-making and negotiating role } \\
\text { responsibilities }\end{array}$ \\
\hline
\end{tabular}




\begin{tabular}{|l|l|l|}
\hline $\begin{array}{l}\text { Utilizes leadership, team building, negotiation, } \\
\text { and conflict resolution skills to build community } \\
\text { partnerships }\end{array}$ & $\begin{array}{l}\text { Provides leadership in the coordination of multidisciplinary } \\
\text { health care teams for integrated delivery of patient care } \\
\text { services }\end{array}$ \\
\hline Accomplishes effective community engagements & $\begin{array}{l}\text { Provides for } \\
\text { continuity within the } \\
\text { plan }\end{array}$ & \\
\hline
\end{tabular}

\section{Note}

${ }^{a}$ As an example, only three of eight competencies in the Quad Council domain of Community Dimensions of Practice Skills are shown.

${ }^{b}$ Competency statements adapted from American Nurses Association (2008). Home health nursing: Scope and standards of practice . Silver Spring, MD: American Nurses Association. 
Final steps included reviewing across the competency grids to identify similarities and differences. Specialty competencies that did not conceptually correspond with any of the Quad Council statements were reviewed for patterns or themes. In turn, Quad Council domains that were minimally or not addressed by specialty competencies were identified. Lastly, the panel of national practice leaders from across the four community-based specialties and nationally recognized practice leaders from traditional public health reviewed and validated the cross-mapping work. These practice leaders then further explored with faculty during joint discussions and email exchanges how best to address gaps in the cross-mapping where specialty content areas were not conceptually congruent with the Quad Council competencies.

\section{Cross-Mapping Outcomes}

Overall, the Quad Council competencies cross-mapped closely with community-based specialty competencies. In some instances, interpretation by expert faculty was necessary to determine appropriate conceptual linkages between the more encompassing Quad Council statements and the narrower, specific specialty competencies. For example, whereas the broader Quad Council competencies around program planning were consistent with the occupational health nursing competencies of developing and managing case management programs, the Quad Council statements did not capture the specific knowledge and skills related to case management. In general, the Quad Council competencies did not address community-based specialty content areas around professional role development. The following describes the outcomes of the cross-mapping process and the consistency between the Quad Council competencies and the specialty competency statements.

\section{Home health nursing}

The scope and standards document for home health nursing (ANA, 2008) includes measurement criteria for 15 practice and professional performance standards and these criteria served as the competency statements during the cross-mapping process. Two roles are distinguished based on educational preparation; home health nurse generalist and the advanced practice home health nurse. Although the advanced role is described as either a clinical nurse specialist or nurse practitioner, measurement criteria are not delineated separately for the two advanced roles. As mentioned earlier, only competencies that met the inclusion criteria for the advanced role were included. A proportion of the Quad Council competencies (81\%) cross-mapped to at least one of the advanced role home health nurse competencies (see Table 1). If no advanced role home health nurse competency was identified, but a generalist competency did conceptually align with a Quad Council competency statement, then based on the inclusion criteria we did include the generalist home health competency (see Table 2). Across the eight Quad Council domains, fewer competencies within the Financial Planning and Management Skills (60\%) and the Cultural Competency Skills (60\%) domains mapped to a home health competency (see Table 1). Of the advanced role competencies that met the inclusion criteria, several did not map to a Quad Council competency. These home health competencies were around conceptual areas such as continuity of care, documentation, and professional role development (see Table 3). In addition, competencies associated with traditional aspects of the clinical nurse specialist role, such as serving as a clinical expert or staff development-related skills did not conceptually align with a Quad Council competency. 
Table 3. Community-Based Specialty Competency Areas Not Cross-Mapped to Quad Council Competencies

\begin{tabular}{|l|l|}
\hline $\begin{array}{l}\text { Community-based } \\
\text { specialty }\end{array}$ & Unmapped specialty competency areas \\
\hline Home health nursing & $\begin{array}{l}\text { — Continuity of care, referral } \\
\text { — Documentation, record keeping } \\
\text { — Traditional clinical nurse specialist role (clinical expert, staff } \\
\text { development) } \\
\text { - Professional role (professional development, self-appraisal, mentor, } \\
\text { consulting, dissemination) }\end{array}$ \\
\hline School nursing & $\begin{array}{l}\text { - Individual health plans } \\
\text { — Coordinated school health program } \\
\text { — Ethics, confidentiality, advocacy } \\
\text { - Professional role (ongoing professional development, self-appraisal, } \\
\text { certification) }\end{array}$ \\
\hline $\begin{array}{l}\text { Occupational health } \\
\text { nursing }\end{array}$ & $\begin{array}{l}\text { - Integrated disability management } \\
\text { - Case management } \\
\text { — Safety, environmental hazards } \\
\text { — Professional role (mentor, consulting, dissemination) }\end{array}$ \\
\hline
\end{tabular}

Note

As all of the environmental health principles cross-mapped to a Quad Council competency, there are no unmapped areas.

\section{School nursing}

Similar to the home health nursing document, the school nursing document included measurement criteria for 15 practice and professional performance standards, with one additional professional performance standard on program management. We used the measurement criteria as competencies for two of the described roles that were distinguished based on educational preparation: School Nurse (generalist) and Nursing Role Specialty (ANA, 2005). The competencies related to the advanced practice nursing role were excluded based on criteria described earlier. The majority (85\%) of the Quad Council competencies were successfully cross-mapped to at least one of the school nursing competencies that met inclusion criteria. However, few school nursing competencies aligned with the Quad Council domain of Cultural Competency Skills (40\%) (see Table 1). In addition, several school nursing competencies did not conceptually align with any of the Quad Council competencies. These school nurse competencies were related to school nurse-specific content such as aspects of a coordinated school health program or professional role development (e.g., ongoing professional development, self-appraisal, and certification) (see Table 3).

\section{Occupational health nursing}

The occupational and environmental health nursing document (AAOHN, 2007) identified competencies focused on the workplace environment within nine categories or domains such as, clinical practice, case management, workforce/workplace/environment, regulatory/legislative, health promotion/disease prevention, and health and safety education/training. Competencies are described as being on a continuum, across levels defined as competent, proficient, or expert; these levels are 
based on experience and skills rather than educational preparation. All of the occupational health nursing competencies met the inclusion criteria for the cross-mapping process and the majority (82\%) of the Quad Council competencies mapped to at least one of this specialty's statements (see Table 1). As with the previous specialties, fewer (20\%) of the occupational health nursing competencies aligned with the Quad Council domain of Cultural Competency Skills. As with the home health and school nursing specialty competencies, occupational health specialty competencies related to the professional role did not conceptually align with a Quad Council competency; additional specialty competencies that did not cross-map are described in Table 3.

\section{Environmental health nursing}

The ANA Principles of Environmental Health document (2007a) describes 10 broad principles that apply to all nurses, regardless of defined specialty; the principles served as a proxy for competency statements. Although environmental health nursing is not currently recognized as a specific community-based specialty with roles defined across levels of practice, graduate nursing education programs in environmental health are emerging and students are expressing interest in specialty roles and clinical activities. Thus, we were interested in how these might guide a curriculum and prepare students for emerging opportunities in specialist roles within environmental health. All of the principles mapped to at least one Quad Council competency, however, only 44\% of the Quad Council statements were consistently mapped to an environmental health principle. Quad Council domains with less than $50 \%$ of the competencies cross-mapped to an environmental health principle included Financial Management Skills (0\%), Analytic Assessment Skills (27\%), Policy Development and Program Planning Skills (27\%), and Communication Skills (43\%) (see Table 1).

\section{Validation by practice leaders}

The above outcomes were shared with our national panel of practice leaders from home health, school, occupational, and environmental health nursing, as well as with nationally recognized practice leaders in traditional public health nursing. Whereas the practice leaders acknowledged that the competency documents used might not reflect the knowledge and skills related to cultural competency and financial planning, all considered these content areas as critical for the current advanced community-based nurses' practice environment. For example, several practice leaders recognized that skill and knowledge in articulating the business case to key stakeholders is critical to garner support for health programming. With the exception of documentation/record keeping skills, all viewed specialty content that did not cross-map to the Quad Council competencies (see Table 3) as essential and therefore necessary to incorporate into a curriculum because it was unrealistic to assume these knowledge and skill sets would be obtained solely via on the job training.

\section{Discussion}

In sum, the substantial conceptual alignment between three of the areas cross-mapped with the Quad Council competencies, namely home health nursing, occupational health nursing, and school nursing specialties, provides assurance that a Quad Council based curriculum is appropriate to prepare graduates in these community-based specialties. These three community-based specialty competencies build from generalist to advanced nursing practice levels, with a corresponding shift from individual plans of care to systems and population focused care and program management. As an 
emerging specialty, specific competencies for environmental health nursing, the fourth cross-mapped area, were not available for this process, and the principles used as proxy measures provided minimal guidance. However, as all of the principle statements aligned with a Quad Council competency, a Quad Council competency-based curriculum remains a viable approach to prepare students in this emerging specialty.

Although we identified some variance in the cross-mapping process, community-based specialty practice professionals value a curriculum based on the broader Quad Council competencies as validated by our national panel of experts. However, the challenge remains as how to best address specialty-specific content when additional courses may not be supported during times of fiscal restraint and lower enrollment in traditional public health and community-based specialty graduate programs. Approaches under development by the authors to address specialty-specific content include expanding and refining the use of case studies and specialty breakout sessions/seminars. Clinical settings and preceptors, along with clinical activities are used to guide student learning towards meeting specific community-based specialty competencies. Programs of study are now developed to include cognate hours, where students can select from electives offered within the university setting or from other universities via cooperative arrangements. For example, courses on workplace safety are available from several of the university-based Educational Resource Centers funded by the National Institute of Occupational Safety and Health. Students then apply the knowledge and skills gained from these cognate courses in clinical activities within a systems/population focus. In addition, as several community-based specialties included competencies associated with the professional role, the curriculum should include activities to guide the student towards ongoing professional development expectations such as competency self-appraisal, planning for certification in advanced public health nursing, and exploring opportunities for professional presentation and publication. Finally, an additional planned step is how competency achievement across the curriculum will be measured (Swider et al., 2006).

Professional competencies evolve as practice changes; at the time of this writing several of the competency documents used in this process are or have been revised. An example is the recently released second edition of School Nursing: Scope and Standards of Practice (ANA, 2011), which includes a seventeenth standard on environmental health. Environmental health is now incorporated as a professional performance standard into ANA scope and standard documents as these documents undergo revisions (ANA, 2010b). A revised version of the Quad Council competencies was completed in 2011. Although the eight domains remain, competencies are now delineated across three tiers or levels of practice to better reflect contemporary roles in practice settings and to recognize the necessary educational and experiential preparation. Tier 1 focuses on competencies for the generalist public health nurse with a baccalaureate level education. Tier 2 and Tier 3 competencies address the skills and knowledge needed for the masters or doctoral prepared public health nurse at, respectively, the specialist/mid-level and at the executive and/or multisystems-level public health nurse. We will be reviewing these new competencies to ensure continued alignment with the community-based specialties, as well as whether any of the identified specialty-specific content, such as professional role, is addressed in the Quad Council revised competencies. Review of additional competency documents from other community-based specialties, such as hospice and palliative care and faith community 
nursing, may provide additional insights for educational content necessary to prepare advanced nurses in these specialties within a Quad Council-based curriculum.

Maintaining a curriculum that reflects contemporary practice is challenging, and the process detailed here highlights the influence of competencies on an educational program and ultimately the specialty level practice of program graduates. In turn, as educational programs evolve, education influences the refinement and development of new competencies. Such is the case with the advancement of the specialty to the doctorate of nursing practice level. The faculty involved in this cross-mapping process developed a deeper understanding of both the public health and community-based specialty nursing competencies, as well as a broader perspective of the advanced roles across the community-based specialties. The process not only stimulated our thinking about curriculum opportunities but also assured us of the relevancy of a broad-based Quad Council competency-based curriculum. The process was a first step and the outcomes reported here have served as the basis for the development and implementation of a doctorate of nursing practice curriculum in public health nursing.

\section{Acknowledgments}

This work was supported in part by funds from the Division of Nursing (DN), Bureau of Health Professions (BHPr), Health Resources and Services Administration (HRSA), Department of Health and Human Services (DHHS) under grant number D09HP03144 and title APHN Leadership: Strategies for Education and Practice. The information or content and conclusions are those of the authors and should not be construed as the official position or policy of, nor should any endorsements be inferred by the Division of Nursing, BHPr, DHHS or the U.S. Government.

\section{References}

American Association of Colleges of Nursing. (2006). The essentials of doctoral education for advanced nursing practice. Retrieved from http://www.aacn.nche.edu

American Association of Occupational Health Nurses. (2007). Competencies in occupational and environmental health nursing. AAOHN Journal, 55, 442- 447.

American Nurses Association. (2005). School nursing: Scope and standards of practice. Silver Spring, MD: American Nurses Association.

American Nurses Association. (2007a). ANA's principles of environmental health for nursing practice with implementation strategies. Silver Spring, MD: American Nurses Association.

American Nurses Association. (2007b). Public health nursing: Scope and standards of practice. Silver Spring, MD: American Nurses Association.

American Nurses Association. (2008). Home health nursing: Scope and standards of practice. Silver Spring, MD: American Nurses Association.

American Nurses Association. (2010a). Nursing: Scope and standards of practice ( 2nd ed.). Silver Spring, MD: American Nurses Association.

American Nurses Association. (2010b). Recognition of a nursing specialty: Approval of a specialty nursing scope of practice statement, and acknowledgement of specialty nursing standards of practice. Retrieved from http://www.nursingworld.org/MainMenuCategories/Tools/3-SBooklet.pdf

American Nurses Association. (2011). School nursing: Scope and standards of practice ( 2 nd ed.). Silver Spring, MD: American Nurses Association. 
APRN Consensus Work Group \& the National Council of State Boards of Nursing APRN Advisory Committee. (2008). Consensus Model for APRN Regulation: Licensure, Accreditation, Certification \& Education. Retrieved from https://www.ncsbn.org/7_23_08_Consensue_APRN_Final.pdf

Carter, K. F., Kaiser, K. L., O'Hare, P. A., \& Callister, L. C. (2006). Use of PHN competencies and ACHNE essentials to develop teaching-learning strategies for generalist C/PHN curricula. Public Health Nursing, 23, 146- 160.

Council on Linkages Between Academia and Public Health Practice. (2010a). Core competencies for public health professionals. Retrieved from http://www.phf.org/resourcestools/pages/core_public_health_competencies.aspx

Council on Linkages Between Academia and Public Health Practice. (2010b). Crosswalk of the original and recently adopted tier 2 core competencies for public health professionals. Retrieved from http://www.phf.org/resourcestools/pages/core_public_health_competencies.aspx

Ervin, N. E. (2002). Advanced community health nursing practice. Upper Saddle River, NJ: Prentice Hall.

Issel, L. M., Ashley, M., Kirk, H., \& Bekemeier, B. (2012). Public health nursing job descriptions: Are they aligned with professional standards? Journal of Public Health Management and Practice, 18, E1-E8.

Ivanov, L. L., \& Blue, C. L. (2008). Public health nursing: Leadership, policy \& practice. Clifton Park, NJ: Delmar.

Jakeway, C. C., Cantrell, E. E., Cason, J. B., \& Talley, B. S. (2006). Developing population health competencies among public health nurses in Georgia. Public Health Nursing, 23, 161- 167.

Levin, P. F., Cary, A. H., Kulbok, P., Leffers, J., Molle, M., \& Polivka, B. J. (2008). Graduate education for advanced practice public health nursing: At the crossroads. Public Health Nursing, 25, 176- 193.

National Academy of Sciences. (2011). The future of nursing: Leading change, advancing health. Washington, DC: The National Academy Press.

Oppewal, S., Lamanna, B. F., \& Glenn, L. L. (2006). Comparison of the dissemination and implementation of standardized public health nursing competencies in academic and practice settings. Public Health Nursing, 23, 99- 107.

Pohl, J. M., Savrin, C., Fiandt, K., Beauchesne, M., Drayton-Brooks, S., Scheibmeir, M., et al. (2009). Quality and safety in graduate nursing education: Cross-mapping QSEN graduate competencies with NONPF's NP core and practice doctorate competencies. Nursing Outlook, 57, 349- 354.

Quad Council of Public Health Nursing Organizations. (2003). Quad Council public health nursing competencies. Retrieved from http://www.resourcenter.net/images/ACHNE/Files/Final_PHN_Competencies.pdf

Quad Council of Public Health Nursing Organizations. (2011, Summer). Quad Council competencies for public health nurses. Retrieved from http://quadcouncilphn.org/

Swider, S., Levin, P. F., Cowell, J. M., Breakwell, S., Holland, P. \& Wallinder, J. (2009). Community/public health nursing $(\mathrm{C} / \mathrm{PHN})$ practice leaders views of the doctorate of nursing practice. Public Health Nursing, 26, 405-411.

Swider, S., Levin, P., Ailey, S., Breakwell, S., Cowell, J., McNaughton, D., et al. (2006). Matching a graduate curriculum in public/community health nursing to practice competencies: The Rush University experience. Public Health Nursing, 23, 190- 195.

Wells, E. V., Sarigiannis, A. N., \& Boulton, M. L. (2012). Assessing integration of clinical and public health skills in preventive medicine residencies: Using competency mapping. American Journal of Public Health, 102, S357- S367. 